\title{
Tunagrahita Student Learning Expert System with Backward Chaining Method at YKDW 01 Tangerang School
}

\author{
Rachmat Hidayat \\ Bina Sarana Informatika University Jakarta \\ West Jakarta \\ rachmat.rch@bsi.ac.id \\ Haryanto \\ Bina Sarana Informatika University \\ West Jakarta \\ haryanto.hyt@bsi.ac.id \\ Pipin Sapinah \\ STMIK Nusa Mandiri Jakarta \\ Central Jakarta \\ pipinsapinah@gmail.com
}

\begin{abstract}
In general, a person's learning habits are influenced by personality variables. Not a few parents who do not understand the effective learning methods for children, parents and teachers must approach first to determine the personality and habits of children, especially children with mental retardation. The learning method given to children is very important, therefore the teaching method applied by parents at home and given by the teacher must be the same to facilitate children in understanding the lesson and not experiencing confusion because they accept different learning methods. This is very influential because there are still many students with disabilities who are still having difficulty understanding learning, especially reading, writing, and counting where learning will be very influential for the community. Based on these problems the researcher requires the application of expert systems using backward chaining to facilitate parents in providing home learning in accordance with the learning methods provided by the teacher in the school so that students are easier and faster in understanding the lesson. From the results of the Research Expert System Application the learning method provided can only be used for students with mental retardation with mild and moderate levels found in the same class, but cannot be used to a more severe level.
\end{abstract}

Keywords - Backward Chaining; Children with mental retardation; Learning Methods, expert systems

\section{INTRODUCTION}

According to[1] suggesting that mentally retarded children are those who have a level of intelligence far below the average of children in general, so they are not able to take part in the program at school. They need special education services. Children with mental retardation are everywhere, both in the city and in the village. They are unable to think abstract and convoluted things. Likewise in lessons such as composing, counting, and other academic subjects
Every child has a different habit of learning. In general, a person's learning habits are influenced by personality variables. Not a few parents who do not understand about effective learning methods for children and get angry quickly when faced with children who are less responsive to the learning provided, therefore we need a prior understanding of the personality of a child.

According to [2] said that one characteristic of mentally retarded children is the inability to think abstractly and easily forget, therefore in teaching mathematics subject matter indirectly 
at the learning stage in the abstract but must be gradual starting from concrete, semi-concrete stages and abstract. The reasoning ability of mentally retarded children is limited to concrete thinking stages. Therefore there is a high probability that teachers who teach mathematics in mentally retarded students have a specific strategy in the learning process. A teacher must have a mature plan before entering the Teaching and Learning Process (PBM), they must always have creative ideas in learning.

To find out the personality of the child, parents must approach first in order to find out the personality and habits of children, especially children with mental retardation. According to observations, the authors do not a few mentally retarded students who have difficulty in counting, their average ability to count is only up to 20. Some students find it difficult to receive instructions when asked to choose one answer from three choices. Besides that due to the limitations of the language they mastered, mentally retarded students experience difficulties in reading and writing. According to some experts, interview authors, the way of learning provided by teachers and parents must be the same so that it can facilitate children in understanding the lessons and more mature understanding of children.

According to [3] "mental retardation is a child with special needs who has intelligence below the average, which ranges between 50-70. They experience obstacles in carrying out any activities, especially in learning.

There are several types of mentally retarded children, with different characteristics and levels of obstetrics, some are mild, moderate and severe. Low-level mentally retarded children are usually difficult in abstract thinking, but they are still able to take academic lessons in both ordinary schools and special schools (SLB). But along with the increasingly difficult learning material, it is better for parents not to be too proud to put their children in Extraordinary Schools because not all children with low mental retardation can take lessons like normal children. Moderate mentally retarded children cannot learn academic subjects. Language development is very limited because the vocabulary is very lacking. They need an accompanying teacher, although they are still able to distinguish between danger and not a danger. The age of intelligence is the same as a normal seven-year-old child. While mentally retarded children with more severe levels throughout their lives need help and help from others, so that all activities such as dressing, eating and so on must be helped. They cannot tell which danger or not. His words and sayings are very simple. His intelligence reaches as high as a normal child who is three years old.

According to [4] suggests that parents and the environment are expected to understand mentally retarded children by not fixating on developmental tasks. Development tasks are only used as triggers, parents help as optimally so that children can go beyond each period of development naturally according to their limitations.

\section{RESEARCH METHODS}

\section{A. Expert System}

Information system that contains the knowledge of an expert so that it can be used for consultation.

An expert system [5] is a computer program that contains knowledge from one or more human experts regarding a specific field. This type of program was first developed by researchers in artificial intelligence in the 1960s and 1970s and was applied commercially during the 1980s. The general form of expert systems is a program created based on a set of rules that analyze information (usually given by users of a system) about a class of specific problems and mathematical analysis of the problem. Depending on the design, the expert system is also able to recommend a series of user actions to be able to apply corrections.

According to Yulianti (2016: 1), the expert system is one of the fields of artificial intelligence (AI) that seeks to adopt human knowledge to computers, combine knowledge and search data to solve problems that normally require human expertise.

\section{B. Backward Chaining Method}

The backward chaining method is backward tracking which starts the reasoning from the conclusion (goal), by looking for a set of hypotheses towards facts that support a set of hypotheses.

Backward Chaining method is the opposite of forward chaining where it starts with a 
hypothesis (an object) and asks for information to convince or ignore. Backward chaining inference engines are often called: "ObjectDriven / Goal-Driven". The inference engine is part of an expert system that tries to use the information provided to find the appropriate object.

\section{Flowchart}

According to [6] suggest that, Flowcharts are graphical depictions of steps and sequence of procedures of a program. Flowcharts help analysts and programmers to solve problems into smaller segments and help in analyzing other alternatives in operation. Flowcharts usually make it easier to solve a problem, especially a problem that needs to be studied and evaluated further. Flowchart is a form of image / diagram that has a one or two-way sequential flow. Flowcharts are used to represent and design programs. Therefore the flowchart must be able to represent components in a programming language.

\section{RESULTS AND DISCUSSION}

Based on the results of interviews from several outstanding school teachers in Tunagrahita Tangerang it can be concluded that the learning method is a way of applying learning that is appropriate to the characteristics of each child in carrying out thinking, behaving, absorbing information, processing and understanding information and reminding it in memory. Here are some types of learning methods for children with mental retardation at the elementary school level according to their respective characteristics.

1. Children have difficulty learning to read

TABLE 1 Children have difficulty learning to read

\begin{tabular}{|c|l|}
\hline Code Method & \multicolumn{1}{|c|}{ Characteristic } \\
\hline MB1 & $\begin{array}{l}\text { Easy to switch attention and } \\
\text { lack concentration }\end{array}$ \\
\cline { 2 - 2 } & $\begin{array}{l}\text { Two explanations must be } \\
\text { given }\end{array}$ \\
\cline { 2 - 2 } & $\begin{array}{l}\text { Weak memory and low } \\
\text { reasoning }\end{array}$ \\
\cline { 2 - 2 } & $\begin{array}{l}\text { Language development is } \\
\text { limited }\end{array}$ \\
\hline MB2 & Can do light work \\
\cline { 2 - 2 } & Able to recognize languages \\
\hline
\end{tabular}

\begin{tabular}{|l|l|}
\hline & $\begin{array}{l}\text { Can respond well when given } \\
\text { a lesson }\end{array}$ \\
\cline { 2 - 2 } & Nice to socialize \\
\hline MB3 & $\begin{array}{l}\text { Cannot store too many or } \\
\text { difficult instructions }\end{array}$ \\
\hline
\end{tabular}

Source (Tunagrahita Foundation)

2. Children learn to write slowly

TABLE 2 Children Hard to Learn to Write

\begin{tabular}{|c|l|}
\hline $\begin{array}{c}\text { Code } \\
\text { Method }\end{array}$ & \multicolumn{1}{|c|}{ Characteristic } \\
\hline \multirow{2}{*}{ MB4 } & It's hard to hold the right pencil \\
\cline { 2 - 2 } & Quitter \\
\cline { 2 - 2 } & Write with intermittent writing \\
\cline { 2 - 2 } Write in no order \\
\hline \multirow{2}{*}{ MB5 } & Happy to draw \\
\cline { 2 - 2 } & $\begin{array}{l}\text { Easily bored and often goes } \\
\text { away while studying }\end{array}$ \\
\hline & $\begin{array}{l}\text { Can write but it is difficult to } \\
\text { copy the writing on the board }\end{array}$ \\
\cline { 2 - 2 } & $\begin{array}{l}\text { Difficult to distinguish letters } \\
\text { and numbers written }\end{array}$ \\
\hline
\end{tabular}

3. Children have difficulty learning to count

TABLE .3 Children Difficult to Learn to Calculate

\begin{tabular}{|c|l|}
\hline $\begin{array}{c}\text { Code } \\
\text { Method }\end{array}$ & \multicolumn{1}{|c|}{ Characteristic } \\
\hline MB7 & $\begin{array}{l}\text { Difficult to communicate with } \\
\text { children }\end{array}$ \\
& Difficult to capture information \\
\cline { 2 - 2 } & $\begin{array}{l}\text { Weak memory and low } \\
\text { reasoning }\end{array}$ \\
& $\begin{array}{l}\text { Cannot store too many or } \\
\text { difficult instructions }\end{array}$ \\
\cline { 2 - 2 } & Emotional \\
\hline MB8 & $\begin{array}{l}\text { More like playing than } \\
\text { learning }\end{array}$ \\
& $\begin{array}{l}\text { Easily bored and often goes } \\
\text { away while studying }\end{array}$ \\
\cline { 2 - 2 } & Nice to play gadget \\
\hline
\end{tabular}

Source (Tunagrahita Foundation) 


\section{A. Expert System Algorithm}

Here is an algorithm from the system that the author designed

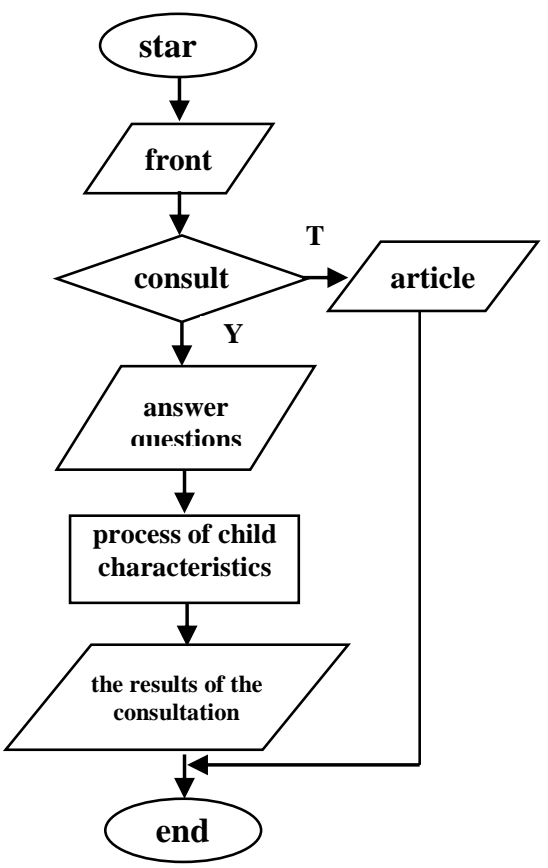

Fig .1 Expert System Algorithm

\section{B. Expert Table}

From interviews with experts, an expert table can be created which lists the learning methods and characteristics. The author found several characteristics of children and appropriate learning alternatives.

TABLE 4 Study method

\begin{tabular}{|c|c|}
\hline No & code method \\
\hline 1 & MB1 \\
\hline 2 & MB2 \\
\hline
\end{tabular}

\begin{tabular}{|l|l|}
\hline 3 & MB3 \\
\hline 4 & MB4 \\
\hline 5 & MB5 \\
\hline 6 & MB6 \\
\hline 7 & MB7 \\
\hline
\end{tabular}

TABLE .5 Characteristics of Students

\begin{tabular}{|c|c|l|}
\hline No & Code & \multicolumn{1}{|c|}{ Characteristics } \\
\hline 1 & K01 & $\begin{array}{l}\text { Easy to switch attention and } \\
\text { lack concentration }\end{array}$ \\
\hline 2 & K02 & Two explanations must be given \\
\hline 3 & K03 & Cando light work \\
\hline 4 & K04 & $\begin{array}{l}\text { Weak memory and low } \\
\text { reasoning }\end{array}$ \\
\hline 5 & K05 & Able to recognize languages \\
\hline 6 & K06 & $\begin{array}{l}\text { Can respond well when given a } \\
\text { lesson }\end{array}$ \\
\hline 7 & K07 & $\begin{array}{l}\text { Cannot store too many or } \\
\text { difficult instructions }\end{array}$ \\
\hline 8 & K08 & $\begin{array}{l}\text { Language development is } \\
\text { limited }\end{array}$ \\
\hline 9 & K09 & Nice to socialize \\
\hline 10 & K10 & It's hard to hold the right pencil \\
\hline 11 & K11 & Quitter \\
\hline 12 & K12 & $\begin{array}{l}\text { Can write but it is difficult to } \\
\text { copy the writing on the board }\end{array}$ \\
\hline 13 & K13 & Write in no order \\
\hline 14 & K14 & Happy to draw \\
\hline 15 & K15 & $\begin{array}{l}\text { Difficult to distinguish letters } \\
\text { and numbers written }\end{array}$ \\
\hline 16 & K16 & Write with intermittent writing \\
\hline 17 & K17 & $\begin{array}{l}\text { Easily bored and often goes } \\
\text { away while studying }\end{array}$ \\
\hline 18 & K18 & $\begin{array}{l}\text { Difficult to communicate with } \\
\text { children }\end{array}$ \\
\hline 19 & K19 & Difficult to capture information \\
\hline 20 & K20 & More like playing than learning \\
\hline 21 & K21 & Emotional \\
\hline 22 & K22 & Nice to play gadget \\
\hline & & \\
\hline
\end{tabular}

TABLE 6 Expert Table

\begin{tabular}{|c|c|c|c|c|c|c|c|c|c|c|c|c|c|c|c|c|c|c|c|c|c|c|c|}
\hline $\begin{array}{c}\text { type of } \\
\text { consultatim } \\
\text { (TC) }\end{array}$ & k01 & $\mathrm{k} / 2$ & $\mathrm{~km}$ & $\mathrm{kn}$ & Wo: & KOV & $\mathrm{kN}$ & $\mathrm{WVO}$ & WVI & $\mathrm{k} 10$ & Kll & K12 & K13 & KI4 & K15 & K16 & K17 & Kls & K19 & $\mathrm{K} 20$ & K21 & K.2. & Conctrion \\
\hline TCl & I & $\sqrt{1}$ & & 1 & & & & $\sqrt{1}$ & & & & & & & & & & & & & & & MB1 \\
\hline $\mathrm{TCl}$ & & & $\sqrt{1}$ & & $\sqrt{1}$ & $\sqrt{2}$ & & & 1 & & & & & & & & & & & & & & $\mathrm{MB2}$ \\
\hline $\mathrm{TCl}$ & & & & & & & $\sqrt{1}$ & & & & & & & & & & & & & & & & MB3 \\
\hline $\mathrm{TC2}$ & & & & & & & & & & 1 & 1 & & 1 & & & 1 & & & & & & & $\mathrm{MB4}$ \\
\hline$T C_{2}$ & & & & & & & & & & & & & & 1 & & & 1 & & & & & & MB5 \\
\hline$T C 2$ & & & & & & & & & & & & 1 & & & 1 & & & & & & & & MB6 \\
\hline $\mathrm{TC3}$ & & & & $\sqrt{1}$ & & & v & & & & & & & & & & & 1 & 1 & & 1 & & MB7 \\
\hline $\mathrm{TC3}$ & & & & & & & & & & & & & & & & & 4 & & & 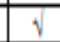 & & 1 & MB8 \\
\hline
\end{tabular}




\section{Explanation of expert Table Flow Algorithms}

IF Question K01 = "Is your child easy to switch attention and lack concentration?" And Answer $=$ "Yes" THEN IF Question K02 = "Should every explanation be given two or three times an explanation should be given?" And Answer = "No" THEN IF Question K04 = "Is memory weak and reasoning low?" and Answer $=$ "No" THEN IF Question K08 = "Is the language development limited?" and Answer = "No" So the Result is the MB01 character code

\section{Expert Decision Tree}

A tree is a hierarchical technique structure consisting of nodes (nodes) that store information or knowledge and branches that connect nodes. A decision tree is made to facilitate decision making. Decision diagram is a simple description of the problem and its solution.

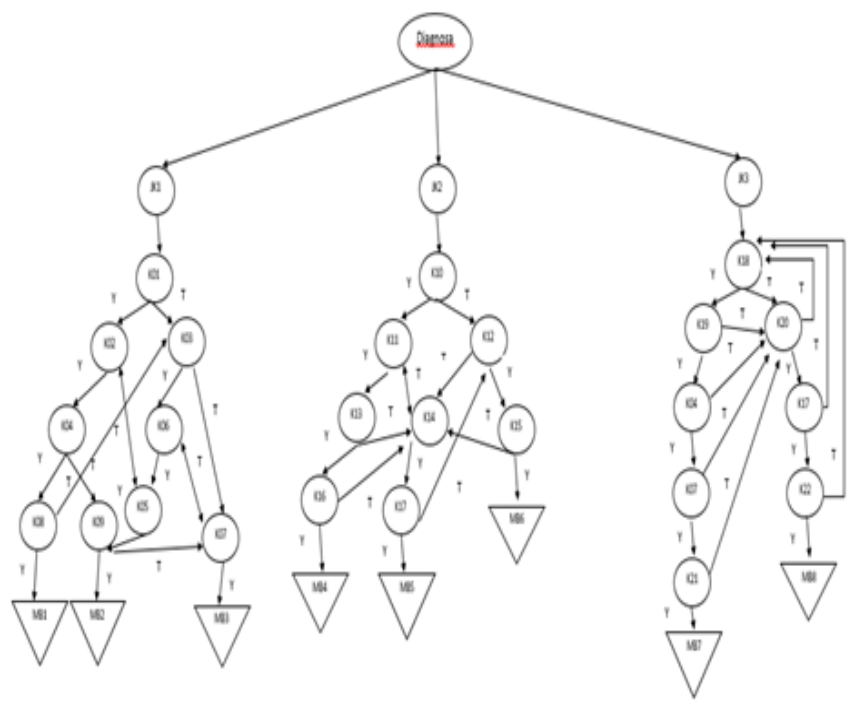

Fig 2 Decision Tree

\section{Software Requirements Analysis}

1) Stages of Analysis

Admin or expert pages can access activities as follows:

A.1.Admin can log in to enter the admin page A.2.Admin or expert can add, delete and edit expert data

A.3.Admin or expert can add, delete and edit student data
A.4.Admin or expert can add, delete and edit types of consultations

A.5.Admin or expert can add, delete and edit question data

A.6.Admin or expert can add, delete and edit learning methods

A.7.Admin or expert can add, delete and edit articles

The user's page can access activities as follows:

B.1. Users can fill in the login to consult

B.2. Users can see the articles on the website

B.3. Users can choose the type of consultation

B.4. Users can consult by answering several questions according to the diagnosis they wish to consult

B.5. Users can see the results of learning methods that are suitable for children

\section{2) Use Case Diagram}

a) Use Case Diagram of User Access Rights

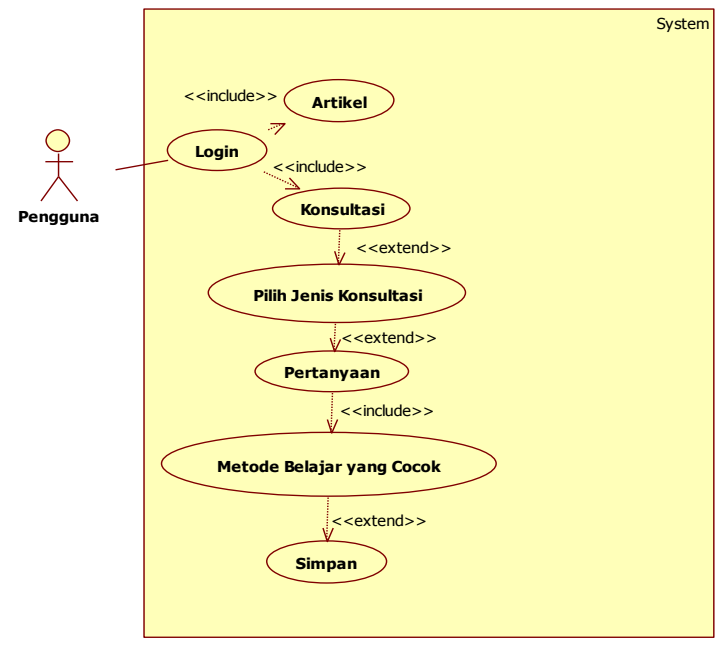

Fig .3 User Access Rights Chart

b) Use Case Admin Access Rights Chart 


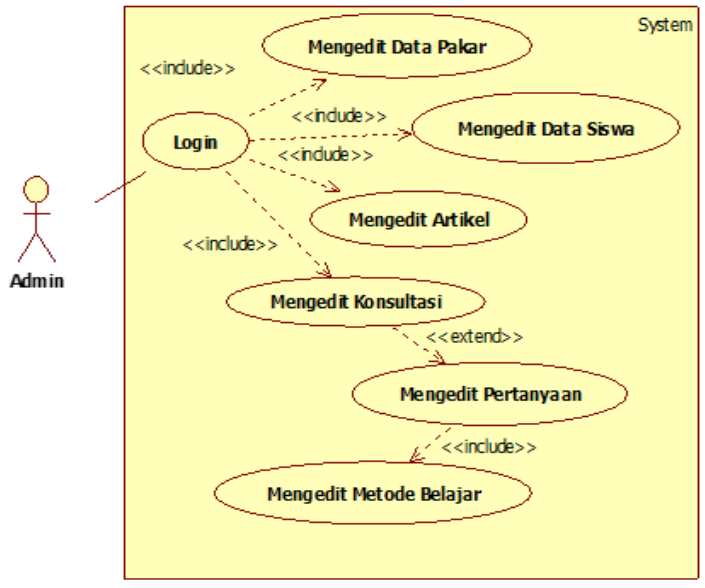

Fig .4 Admin Access Rights Chart

\section{E. Design}

At this stage, it will explain the database design, software architecture and user interface of the proposed system.

\section{1) Database}

Entity Relationship Diagram is a model that explains the relationship between data in a database based on basic data objects that have relationships between relations.

The following is the initial Entity Relationship Diagram that is used to obtain a minimizing database design that can accommodate data storage of the system being reviewed.

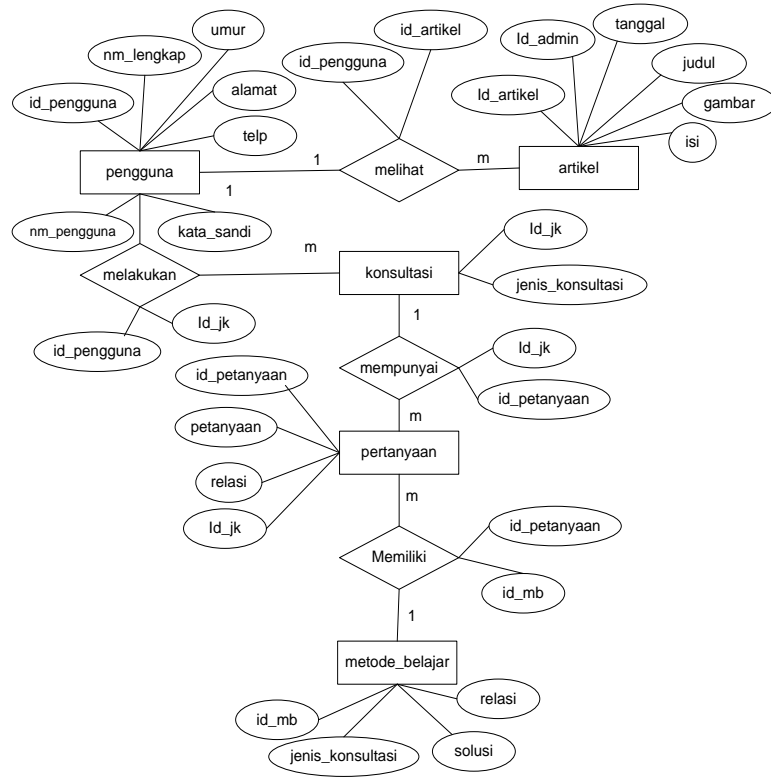

Fig .5 Entity Relationship Diagram

\section{2) Display of Expert System Applications}

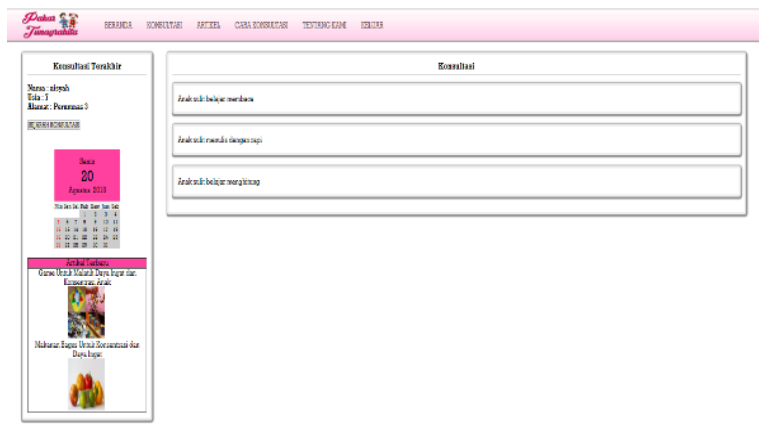

Fig .6 Diagnosis of User Pages

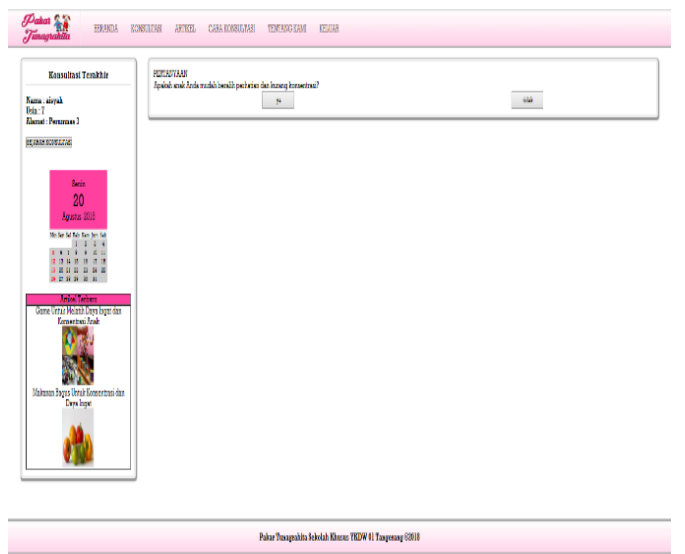

Fig .7 Consultation on User Pages

\section{CONCLUSION}

This system uses learning methods that are in accordance with the applicable curriculum based on the results of interviews that the authors examined at the YKDW 01 Tangerang Special School and the Markus Education Foundation in Tangerang.

In making this expert system there are several conclusions, including:

1. Learning methods provided by parents and teachers become the same and learning methods provided in accordance with the curriculum applied in special schools so that children do not experience confusion because they get different learning methods and make it easier for children to understand the lesson.

2. Make it easier for parents who have busy work outside and want to consult on the 
learning methods of children with mental retardation.

3. In this system, the learning method provided is only for students with mental retardation with mild and moderate levels in the same class.

\section{REFERENCES}

[1] A. Setiawan, Dani E;Mais, "Pengaruh Tingkat Kehadiran Siswa Terhadap Efektivitas Proses Pembelajaran Siswa Kelas IV Tunagrahita Ringan dalam Kelas Reguler SD Inklusi di Kabupaten Jember," J. Spec. Educ., vol. 1, pp. 28-33, 2017.

[2] I. Utami, dewi aninta; sujadi, "Strategi Guru dalam Membelajarkan Matemati kapada Materi Lingkaran Kepada Anak Tunagrahita (Studi Kasus pada Siswa Kelas VIII SLB Muhammadiyah Cepu)," J. Pembelajaran Mat., vol. 2, pp. 853-864, 2014.

[3] F. Sefni, "EFEKTIFITAS METODE PROYEK PADA PEMBELAJARAN KETERAMPILAN BAGI ANAK TUNAGRAHITA SEDANG KELAS $\mathrm{X}$ SMALB DI YPAC SUMBAR," J. Ilm. Pendidik. KHUSUS, vol. 3, pp. 182-191, 2014.

[4] E. Novita, "PERBEDAAN PENERIMAAN DIRI IBU YANG MEMILIKI ANAK TUNAGRAHITA DITINJAU DARI TINGKAT PENDIDIKAN DI SLB-E PTP MEDAN," Diversita, vol. 3, pp. 55-62, 2017.

[5] Wikipedia, "Sistem pakar," 2019. [Online]. Available: https://id.wikipedia.org/wiki/Sistem_pakar

[6] R. Hidayat, "Sistem Informasi Ekspedisi Barang Dengan Metode E-CRM Untuk Meningkatkan Pelayanan Pelanggan," $J$. SISFOTEK Glob., vol. 4, pp. 41-45, 2014. 